Przegląd Prawa Konstytucyjnego

- -ISSN 2082-1212--------

DOI 10.15804/ppk.2016.02.03

$-\mathrm{Nr} 2(30) / 2016$

Anna Pazura' ${ }^{1} \quad$ Jan Uniejewski²

\title{
Konwencja o Ochronie Praw Człowieka i Podstawowych Wolności jako fundamentalny akt prawa europejskiego - czy twierdzenie to nadal zachowuje aktualność?
}

Słowa kluczowe: Rada Europy, Konwencja o Ochronie Praw Człowieka i Podstawowych Wolności, Europejski Trybunał Praw Człowieka, skarga indywidualna, instrument konstytucyjnego europejskiego porządku publicznego w dziedzinie praw człowieka, umowa międzynarodowa, prawa człowieka, Karta Praw Podstawowych Unii Europejskiej Keywords: the Council of Europe, the Convention for the Protection of Human Rights and Fundamental Freedoms, the European Court of Human Rights, an individual application, the constitutional instrument of the European public order in the field of human rights, international agreement, human rights, the Charter of Fundamental Rights of the European Union

\section{Streszczenie}

Konwencja o ochronie praw człowieka i podstawowych wolności niejednokrotnie była określana mianem fundamentalnego aktu prawa europejskiego. Prezentowane rozważania, poprzez charakterystykę okoliczności jej powstania, normatywnej treści, mechanizmu implementacyjnego oraz aktualnego kontekstu, w jakim obowiązuje, zmierzają do wykazania, czy twierdzenie to pozostaje zasadne w aktualnej rzeczywistości prawno-politycznej. Nie budzi co prawda wątpliwości, że to właśnie w Konwencji państwa-sygnatariusze po raz pierwszy przyjęly na siebie prawne zobowiązanie ochrony podstawo-

1 Autorka jest asystentem w Katedrze Prawa Konstytucyjnego i Integracji Europejskiej Wydziału Prawa i Administracji Uniwersytetu Szczecińskiego. E-mail: les65an89@o2.pl.

2 Autor jest doktorantem w Katedrze Prawa Konstytucyjnego i Integracji Europejskiej Wydziału Prawa i Administracji Uniwersytetu Szczecińskiego. E-mail: jan_uniejewski@wp.pl. 
wych wolności i praw człowieka, a co szczególnie istotne - wyraziły zgodę na to, by każda jednostka mogła kierować przeciwko każdemu z nich skargi indywidualne, wnoszone do specjalnie powołanego międzynarodowego organu sądowego kompetentnego do wiążącego rozstrzygania, czy doszło do naruszeń chronionych wolności lub praw. Był to przełomowy moment $\mathrm{w}$ rozwoju prawa międzynarodowego, w którym przez wieki zakorzeniło się przekonanie, że rozstrzyganie o wolnościach i prawach jednostek należy do jurysdykcji krajowej, a jednostki nie mają podmiotowości międzynarodowo-prawnej. Konwencja stworzyła zatem mechanizm implementacyjny, którego rola w zakresie wytyczania standardów ochrony wolności i praw człowieka jest nie do przecenienia. Niemniej jednak nie można tracić z pola widzenia, że funkcjonowanie w europejskiej przestrzeni prawnej Karty Praw Podstawowych Unii Europejskiej oraz słabość Rady Europy, przejawiająca się w zrzeszaniu dużej liczby państw o dość zróżnicowanej kulturze prawnopolitycznej oraz zróżnicowanych standardach demokracji, sprawiają, że praktyczna doniosłość Konwencji ulega i - jak należy się spodziewać - będzie ulegać nieustannej weryfikacji.

\section{Summary}

\section{Convention for the Protection of Human Rights and Fundamental Freedoms as a fundamental instrument of the European law - does this statement still remain valid?}

Convention for the Protection of Human Rights and Fundamental Freedoms is often referred as a fundamental instrument of the European law. The following study, through a detailed description of the circumstances of creation of the Convention, its normative content, enforcement mechanism and the current context in which it is in force, seeks to demonstrate whether the above statement remains valid in the current political and legal reality. It is true that in the Convention sovereign states accepted for the first time legal obligations to secure the classical human rights and freedoms and - what is particularly relevant - to allow all individuals to bring applications against the state, leading to a specially founded international judicial body finding them in breach. This was a crucial, revolutionary step in the evolution of the international law that, for centuries, had been based on such deeply entrenched foundations as the ideas that the settlement of the freedoms and rights of individuals was within the domestic jurisdiction of states and that individuals were not subjects of rights in this law. The Convention has thus generated the effective enforcement mechanism in the world, which contribution to the setting of standards for the protection of human rights and freedoms is unrivalled. However, it cannot be lost from one's sight that currently the presence of the Charter of Fundamental Rights of the European Union in the European legal space and the weakness of the Council of Europe, under of which auspices the European Convention on Human Rights was adopted, mani- 
festing itself in the fact that it associates a large number of countries with quite diverse political and legal culture and the standards of democracy, make the practical importance of the Convention be the subject of constant verification.

\section{I.}

Rada Europy (zwana dalej „RE”) jako „organizacja wartości”3 zorientowana jest na tworzenie i promowanie standardów demokracji, praworządności i praw człowieka w państwach członkowskich. Spośród ponad 200 umów międzynarodowych wypracowanych i przyjętych pod jej auspicjami największą doniosłość przypisuje się Europejskiej Konwencji o Ochronie Praw Człowieka i Podstawowych Wolności z 4 listopada 1950 r. (dalej zwaną „EKPCz” lub „Konwencją”) ${ }^{4}$, stanowiącej trzon europejskiego systemu ochrony praw człowieka. Przyjęcie Konwencji (w sferze prawnej rozumiane jako przystąpienie do umowy międzynarodowej) stanowi warunek sine qua non członkostwa w tej organizacji. Nie oznacza to jednak obowiązku przystąpienia do wszystkich jej protokołów dodatkowych ${ }^{5}$. W konsekwencji protokoły wchodzą w życie po ratyfikacji przez określoną liczbę państw ${ }^{6}$ i wiążą wyłącznie państwa, które do nich przystąpiły, a następnie ratyfikowały

3 J. Jaskiernia, Rada Europy jako „organizacja wartości”, [w:] Wyjaśnianie polityki, red. J. Błuszkowski, J. Zaleśny, Warszawa 2010, s. 178.

4 Dz.U. 1993, Nr 61, poz. 284 ze zm.

5 Np. Protokół nr 1 nie został ratyfikowany przez dwa państwa: Monako i Szwajcarię -http://www.conventions.coe.int/Treaty/Commun/ChercheSig.asp?NT=009\&CM=8\&D$\mathrm{F}=10 / 10 / 2014 \& \mathrm{CL}=\mathrm{ENG}$ (11.08.2015); Protokół nr 4 nie został ratyfikowany przez cztery państwa: Grecję, Szwajcarię, Turcję i Wielką Brytanię -http://www.conventions.coe.int/Treaty/Commun/ChrecheSig.asp? $\mathrm{NT}=046 \& \mathrm{CM}=8 \& \mathrm{DF}=10 / 10 / 2014 \& \mathrm{CL}=\mathrm{ENG}$ (11.08.2015); Protokół nr 7 nie został ratyfikowany przez cztery państwa: Niemcy, Holandię, Turcję i Wielką Brytanię -http://www/conventions.coe.int/Treaty/Commun/ChercheSig.asp?NT=117\&C$\mathrm{M}=8 \& \mathrm{DF}=10 / 10 / 2014 \& \mathrm{CL}=\mathrm{ENG}$ (11.08.2015); Protokół nr 13 nie został ratyfikowany przez trzy państwa: Armenię, Azerbejdżan i Rosję - http://www.conventions.coe.int/Treaty/Commun/ChercheSig.asp?NT=187\&CM=8\&DF=10/10/2014\&CL=ENG (11.08.2015).

6 Wymaganą liczbę ratyfikacji określają postanowienia końcowe zawarte $\mathrm{w}$ danym protokole. 
zgodnie z wymogami krajowymi. Zaś Konwencja - z uwagi właśnie na swój fundamentalny charakter będący przedmiotem niniejszych uwag - wiąże wszystkie państwa członkowskie RE, niezależnie od przyjęcia przez nie protokołów dodatkowych.

Celem niniejszego artykułu jest dokonanie charakterystyki EKPCz pod kątem jej konstrukcji prawnej, zawartości normatywnej oraz aktualnego kontekstu, w jakim obowiązuje, a w konsekwencji wykazanie, czy aktualne pozostaje twierdzenie, że Konwencja w pełni zasługuje na miano fundamentalnego aktu prawa europejskiego; prawa europejskiego rozumianego bardzo szeroko, jako ogółu norm prawnych wyodrębnionych (wywodzonych) z różnych aktów prawnych, w szczególności ratyfikowanych umów międzynarodowych, których cechą szczególną jest terytorialny zasięg obowiązywania, a zatem nie ograniczanego wyłącznie do prawa Unii Europejskiej (dalej jako „UE”).

II.

Za punkt wyjścia rozważań przyjąć należy grunt historyczny, w jakim doszło do przyjęcia EKPCz. W istocie zostało ono zainspirowane dwoma faktami. Z jednej strony, bolesnymi doświadczeniami okresu II wojny światowej, które stały się zasadniczym impulsem tworzenia instrumentów międzynarodowej ochrony praw jednostki, a z drugiej - powszechnym uznaniem, że uchwalenie odpowiedniej konwencji i opracowanie skutecznego mechanizmu jej implementacji stanowi jedną z dróg wiodących do integracji starego kontynentu? ${ }^{7}$ Na konieczność ustanowienia europejskiego forum współpracy w ochronie praw człowieka szczególną uwagę zwracali tzw. Ojcowie Założyciele przyszłej Unii Europejskiej, w tym zwłaszcza Winston Churchill ${ }^{8}$ oraz -w sposób niezrozumiały niemalże zapomniany w Ojczyźnie - wybitny Polak, Józef Retinger ${ }^{9}$.

R. Kuźniar, Prawa człowieka. Prawo, instytucje, stosunki międzynarodowe, Warszawa 2002, s. 173.

8 M. Król, Wielcy władcy. Richelieu, Bismarck, de Gaulle, Churchill, Warszawa 2014, s. 143 i n., A. Kastory, Winston Churchill, Wrocław 2004, s. 419 i n.

9 B. Podgórski, Józef Retinger - prywatny polityk, Kraków 2013, s. 241-244 oraz bardzo krytycznie o J. Retingerze i jego działalności: O. Terlecki, Barwne życie szarej eminencji, Kraków 1981; Idem, Kuzynek diabła, Kraków 1988. 
Idee przyjęcia konwencji obejmującej swym zasięgiem stary kontynent sięgają początków starań o stworzenie RE (od 1948 r., gdy przyjęto Powszechną Deklarację Praw Człowieka ONZ) ${ }^{10}$. Jednakże prace nad projektem Konwencji na forum RE uległy zintensyfikowaniu dopiero po roku, w sierpniu 1949 r. Prace te ostatecznie zakończyły się uroczystym podpisaniem Konwencji w Rzymie 4 listopada 1950 r. ${ }^{11}$

Po uzyskaniu wymaganej liczby ratyfikacji, przez dziesięć krajów członkowskich RE, Konwencja weszła w życie 3 września 1953 r. Obecnie jej stronami jest 47 państw członkowskich, spośród których 28 jest jednocześnie członkiem UE. Rozszerzenie grupy państw stron-Konwencji nie jest przewidywane. De lege lata stroną EKPCz nie jest również UE ${ }^{12}$. Niemniej jednak wejście w życie tzw. Traktatu z Lizbony z 13 grudnia 2007 r., zmieniającego od 1 grudnia 2009 r. Traktat o Unii Europejskiej i Traktat ustanawiający Wspólnotę Europejską ${ }^{13}$, oraz Protokołu nr 14 do Konwencji z 1 czerwca 2010 r., stworzyło niezbędną osnowę prawną dla rozszerzenia tej grupy o $\mathrm{UE}^{14}$. Oficjalne rozmowy gremiów reprezentujących RE i UE w sprawie

10 A. Bisztyga, Ochrona praw człowieka w Radzie Europy, [w:] B. Banaszak, A. Bisztyga, K. Complak, M. Jabłoński, R. Wieruszewski, K. Wójtowicz, System ochrony praw człowieka, Kraków 2003, s. 125.

11 Szczegółowo na temat genezy i prac nad EKPCz - zob. m.in. A. Bisztyga, Geneza Europejskiej Konwencji o Ochronie Praw Człowieka i Podstawowych Wolności oraz Europejskiego Trybunału Praw Człowieka, „Humanistyczne Zeszyty Naukowe - Prawa Człowieka” 1994, nr 1, s. 31-50; Idem, Europejski Trybunat Praw Człowieka, Katowice 1997, s. 27-60; D.J. Harris, M. O’Boyle, E.P. Bates, C.M. Buckley, Law of the European Convention on Human Rights, Oxford 2009, s. 1-3; M.W. Janis, R.S. Kay, A.W. Bradley, European Human Rights Law. Text and Materials. Oxford 2007, s. 3-23; A. Mowbray, Cases and Materials on the European Convention on Human Rights, Oxford 2006, s. 1-10.

12 A. Wróbel, Wprowadzenie. Uwagi ogólne, [w:] Karta Praw Podstawowych Unii Europejskiej. Komentarz, red. A. Wróbel, Warszawa 2012, System Informacji Prawnej Legalis (11.08.2015).

13 Dz.U. 2009, Nr 203, poz. 1569 ze zm.

14 L. Garlicki, Przystapienie UE do Europejskiej Konwencji Praw Człowieka - przygotowania i problemy, „Europejski Przegląd Sądowy” 2011, nr 1, s. 14-19; C. Mik, Przystąpienie Unii Europejskiej do Europejskiej Konwencji o Ochronie Praw Człowieka i Podstawowych Wolności, [w:] Europejska Konwencja Praw Człowieka i jej system kontrolny-perspektywa systemowa i orzecznicza, red. M. Balcerzak, T. Jasudowicz, J. Kapelańska-Pręgowska, Toruń 2011, s. 29-82. 
przystąpienia UE do EKPCz zostały rozpoczęte w lipcu 2010 r. $^{15}$, natomiast już rok później - w lipcu 2011 r. - powstał projekt umowy akcesyjnej (porozumienia $\mathrm{w}$ sprawie przystąpienia), podlegający dalszym negocjacjom i uzgodnieniom ${ }^{16}$. Ostateczny projekt umowy o przystąpieniu został przedłożony 5 kwietnia 2013 r. ${ }^{17}$ Projekt ten był przedmiotem rozważań Trybunału Sprawiedliwości Unii Europejskiej (dalej jako „TS UE”), który w opinii nr 2/13 z 18 grudnia 2014 r. $^{18}$ zidentyfikował liczne problemy zgodności proponowanego porozumienia $z$ prawem Unii. TS UE uznał, że zaproponowane porozumienie nie jest zgodne $\mathrm{z}$ art. 6 ust. 2 TUE ani z Protokołem nr $8^{19}$ w czterech obszarach (art. 258 opinii). Po pierwsze, porozumienie może naruszać szczególne cechy i autonomię prawa Unii, gdyż nie zapewnia korelacji między art. 53 EKPCz i art. 53 Karty Praw Podstawowych UE ${ }^{20}$ (dalej jako „KPP UE” lub „Karta”). Co więcej, nie zapobiega ryzyku naruszenia zasady wzajemnego zaufania między państwami członkowskimi, a nadto w ogóle nie określa stosunku między mechanizmem ustanowionym w Protokole nr 16 (protokół dodatkowy do EKPCz) a procedurą odesłania prejudycjalnego przewidzianą $\mathrm{w}$ art. 267 TFUE. Po drugie, porozumienie może naruszać art. 344 TFUE, gdyż nie wyklucza możliwości wnoszenia do Europejskiego Trybunału Praw Człowieka (dalej jako „ETPCz”) sporów powstałych między państwami członkowskimi lub między nimi a Unią, które dotyczą stosowania EKPCz w ramach prawa Unii. Po trzecie, porozumienie nie przewiduje zasad funkcjonowania mechanizmu współpozwania i procedury wcześniejszego zaangażowania Trybunału, które pozwalałyby zachować

15 Ł. Bojarski, Rada Europy i Europejski Trybunat Praw Człowieka - podstawowe informacje, [w:] Europejska Konwencja Praw Człowieka - Poradnik Praktyczny, red. Ł. Bojarski, M. Krzyżanowska-Mierzewska, Warszawa 2011, s. 16.

16 N. Półtorak, Przystąpienie Unii Europejskiej do Konwencji o Ochronie Praw Człowieka - projekt umowy akcesyjnej a prawo UE, „Europejski Przegląd Sądowy” 2012, nr 9, s. 4 i n.

17 http://www.europapraw.org/news/zakonczenie-negocjacji-w-sprawie-przystapieniaue-do-ekpcz (11.08.2015).

$18 \mathrm{http}: / /$ curia.europa.eu/jcms/upload/docs/application/pdf/2014-12/cp140180pl. $\operatorname{pdf}(11.08 .2015)$.

19 Protokół (nr 8) dotyczący artykułu 6 ustęp 2 Traktatu o Unii Europejskiej w sprawie przystąpienia Unii do Europejskiej Konwencji o Ochronie Praw Człowieka i Podstawowych Wolności.

20 Dz.Urz. UE z dnia 14 grudnia 2007 r., seria C 301/01. 
szczególne cechy Unii i jej prawa. Po czwarte, porozumienie nie uwzględnia szczególnych cech prawa Unii w odniesieniu do kontroli sądowej aktów, działań lub zaniechań Unii w zakresie Wspólnej Polityki Zagranicznej i Bezpieczeństwa, gdyż powierza kontrolę sądową niektórych tych aktów, tych działań lub tych zaniechań wyłącznie organowi zewnętrznemu w stosunku do Unii.

Przyjęta przez TS UE argumentacja opiera się na twierdzeniu o konieczności ochrony prymatu jego orzecznictwa, przy jednoczesnym odwołaniu się do zasady bezwzględnego pierwszeństwa prawa unijnego. Podleganie wyrokom ETPCz (szczególnie w obszarach, które wyłączone są spod jurysdykcji TS UE), przedstawione zostało jako poważne zagrożenie dla niezależności unijnego systemu prawnego. Powzięte wątpliwości są na tyle poważne, że kontynuacja procesu akcesji UE do EKPCz wymagałaby zmian fundamentalnych elementów dokumentu o przystąpieniu lub rewizji traktatów założycielskich. Obydwa rozwiązania, a szczególnie pierwsze (powodujące konieczność uzyskania zgody wszystkich 47 państw członkowskich RE, w tym Rosji),wydają się skomplikowane zarówno proceduralnie, jak i politycznie. W konsekwencji wizja przystąpienia UE do Konwencji rysuje się w dość odległej perspektywie.

W naszej ocenie, przystąpienie UE do EKPCz nie stanowiłoby zagrożenia dla autonomii prawa Unii oraz wyłącznego prawa kontroli i interpretacji prawa unijnego przez TS UE. Szczególne cechy Unii i prawa unijnego, pomimo przyznania zewnętrznej kontroli ETPCz, nie zostałyby bowiem naruszone. Wniosek ten znajduje uzasadnienie przede wszystkim w szczególnej zasadzie działania systemu konwencyjnego - zasadzie subsydiarności ochrony sprawowanej przez ETPCz, która w praktyce po akcesji oznaczałaby, że obowiązek poszanowania praw podstawowych ustanowionych w Konwencji spoczywałby na państwach członkowskich, następnie na organach i instytucjach unijnych, a dopiero po wyczerpaniu tych środków, tj. w przypadku niezapewnienia wystarczającej ochrony - oceny danego prawa czy działania dokonywałby ETPCz. Przystąpienie przyniosłoby zatem wprowadzenie zewnętrznej kontroli realizacji praw człowieka w Unii, ale nie nadałoby ETPCz kompetencji ani do dokonywania zmian, ani uchylania prawa Unii.

W opublikowanym raporcie ze stosowania przez UE Karty Praw Podstawowych w 2014 r. Komisja Europejska potwierdziła, że podejmuje obecnie 
próbę znalezienia jak najlepszego wyjścia z sytuacji zaistniałej w wyniku wydania opinii TS UE z 18 grudnia 2014 r. ${ }^{21}$ Jednakże bliższe szczegóły strategii jej postępowania nie są jak dotąd znane.

\section{III.}

W piśmiennictwie prawniczym, odnoszącym się do prawnej i politycznej doniosłości antycypowanego przystąpienia UE do EKPCz, wskazuje się, że oznaczać ono będzie zwłaszcza włączenie w ramy acquis communautaire ogromnego dorobku orzecznictwa strasburskiego w zakresie interpretacji standardów praw człowieka, a nadto - że stworzony zostanie w ten sposób spójny (koherentny) system ochrony praw podstawowych w Europie. Stanowić on będzie efekt prawnego i instytucjonalnego połączenia dwóch obecnie istniejących odrębnych systemów(konwencyjnego i unijnego). Jednocześnie wskazuje się na bezpośrednie korzyści płynące dla jednostek wchodzących $\mathrm{w}$ relacje prawne ze stronami Konwencji, które polegać mają na wyeliminowaniu ewentualnych rozbieżności w orzecznictwie stojących na straży ich wolności i praw trybunałów, tj. ETPCz i TS UE ${ }^{22}$. Ostatni z przywołanych argumentów traci jednak na doniosłości z uwagi na stanowisko UE wyrażone wobec zagadnień praw człowieka w przepisie art. 52 ust. 3 zdanie 1 KPP UE. Zgodnie z tym postanowieniem, w zakresie, w jakim Karta zawiera prawa odpowiadające prawom zagwarantowanym w Konwencji, ich znaczenie i zakres są takie same (tożsame). Na właściwe rozumienie tego przepisu wskazują same instytucje, które Kartę przyjęły (Parlament Europejski, Rada i Komisja), gdyż w „Wyjaśnieniach dotyczących Karty Praw Podstawowych" ${ }^{23}$, nie mających co do zasady charakteru prawnego, lecz stanowiących cenne narzędzie wykładni przeznaczone do wyjaśnienia postanowień Karty ${ }^{24}$, wskazano, że „w żadnym wypadku poziom ochrony zapewniony w Kar-

${ }^{21}$ http://ec.europa.eu/justice/fundamental-rights/files/2014_annual_charter_report_en.pdf(11.08.2015).

${ }^{22} \quad$ Ibidem, s. 6; zob. również m.in.: A. Płachta, Prawo WE i UE a Konwencja o Ochronie Praw Człowieka i Podstawowych Wolności, [w:] Stosowanie prawa Unii Europejskiej przez sądy, red. A. Wróbel, Warszawa 2010, s. 307-308.

23 Dz.Urz. UE z dnia 14 grudnia 2007 r., seria C 303/10.

24 Por. wstęp do Wyjaśnienia do Karty Praw Podstawowych. 
cie nie może być niższy niż poziom zagwarantowany w Konwencji”. Innymi słowy, skoro konwencyjny poziom ochrony współkształtowany jest nie tylko przez treści samej Konwencji, lecz przede wszystkim przez ETPCz uzupełniający ją w swoim orzecznictwie, to organy UE chcące zapewnić nie niższy poziom ochrony tych wolności i praw z konieczności muszą odwoływać się do orzecznictwa strasburskiego, uwzględniając je w swojej działalności, zwłaszcza w działalności prawodawczej. Uwzględnienie orzecznictwa strasburskiego stanowi zatem konsekwencję tzw. koncepcji najmniejszego wspólnego mianownika, stosowanej również w kontekście tradycji konstytucyjnych państw członkowskich $\mathrm{UE}^{25}$.

Z chwilą przystąpienia UE do Konwencji z pewną dozą ostrożności można - naszym zdaniem - przypuszczać, że otwarta zostanie droga, przynajmniej potencjalnie, dla innych organizacji międzynarodowych, spełniających warunki przewidziane w systemie RE, do przystąpienia do Konwencji.

\section{IV.}

Pod względem prawnym EKPCz jest umową międzynarodową, co sprawia m.in., że jej ratyfikacja rodzi międzynarodowoprawny obowiązek wykonywania jej postanowień, a sposób jej wykładni i stosowania przebiega $\mathrm{w}$ ramach powszechnie uznanych zasad prawa międzynarodowego ${ }^{26}$, zawartych zwłaszcza w Konwencji Wiedeńskiej o Prawie Traktatów z 23 maja 1969 r. $^{27} \mathrm{~W}$ doktrynie i orzecznictwie ETPCz niejednokrotnie podkreśla się, że EKPCz - z uwagi na jej doniosłość i unikalność - jest jednak traktatem szczególnego rodzaju (sui generis), traktatem ustanawiającym prawa człowieka (human rights treaty) ${ }^{28}$. Twierdzenie o rzekomym „ustanawianiu

\footnotetext{
25 Komentarz do art. 52, [w:] Wyjaśnienia do Karty Praw Podstawowych.

26 L. Garlicki, Wprowadzenie, [w:] Konwencja o Ochronie Praw Człowieka i Podstawowych Wolności. T. I. Komentarz do artykułów 1-18, red. L. Garlicki, Warszawa 2010, s. 5.

27 Dz.U. 1990, Nr 74, poz. 439.

28 \ 43 wyroku ETPCz z dnia 18 grudnia 1996 r. w sprawie Loizidou przeciwko Turcji, skarga nr 15318/89, Lex Polonica nr 2351946; \$ 55 wyroku ETPCz z dnia 21 listopada 2001 r. w sprawie Al-Adsani przeciwko Zjednoczonemu Królestwu, skarga nr 35763/97, Lex Polonica nr 398439; \$ 163 wyroku ETPCz z dnia 12 maja 2005 r., w sprawie Öcalan przeciwko Turcji, skarga nr 46221/99, Lex Polonica nr 391130; \$ 56 wyroku ETPCz z dnia 23 marca
} 
praw człowieka”, choć z uwagi na prawno-polityczne znaczenie Konwencji jest właściwe, to jest jednocześnie wewnętrznie kontradyktoryczne, albowiem błędnie zakłada, że prawa człowieka są przez jakąś władzę ustanowione (przydane jednostce). Jak jednak powszechnie wiadomo, prawa człowieka wynikają z samej istoty człowieczeństwa. Żaden człowiek nie musi być w nie wyposażany, gdyż są one jego atrybutem per $e^{29}$. Inną zaś kwestią pozostaje, czy są one respektowane i należycie chronione. Mówiąc o „ustanawianiu praw człowieka”, rozumieć przez to należy raczej skrót myślowy oznaczający właśnie nic innego, jak tylko respektowanie i należytą ochronę tychże praw zarówno w prawie krajowym, jak i międzynarodowym (czego Konwencja jest najlepszym przykładem), a nie ustanowienie w sensie czynności konwencjonalnej tworzącej prawo. Struktura EKPCz została ujęta w sposób nieodbiegający od struktury innych umów międzynarodowych ${ }^{30}$.

Otwierają ją Preambuła, wskazująca genezę powstania, cele (motywy) i system wartości, którego realizacji Konwencja ma służyć. Następnie, w art. 1, wyrażone zostały ogólne zobowiązania jej państw-sygnatariuszy do przestrzegania praw człowieka oraz wyznaczono zakresy - podmiotowy, miejscowy i temporalny (czasowy) - zastosowania Konwencji. Dalszy tekst Konwencji - w jego aktualnym brzmieniu - usystematyzowany został w trzy rozdziały:

1. „Prawa i wolności” (art. 2-18), zawierający katalog chronionych wolności i praw oraz określający zasady ich stosowania,

2. „Europejski Trybunał Praw Człowieka” (art. 19-51), określający ustrój i właściwość Trybunału, status prawny jego sędziów oraz zasady jego procedowania,

3. „Postanowienia różne” (art. 52-59), dotyczące m.in. terytorialnego zakresu stosowania, możliwości składania zastrzeżeń i wypowiedzenia Konwencji, a także jej podpisania i ratyfikowania ${ }^{31}$.

2010 r. w sprawie Cudak przeciwko Litwie, skarga nr 15869/02, Lex Polonica nr 2210543. H. Morawska, K. Gałka, Standardy ochrony praw człowieka w prawie Europejskiej Konwencji Praw Człowieka. Analiza wiodących spraw polskich, Warszawa 2011, s. 6.

29 W. Osiatyński, Prawa człowieka i ich granice, Warszawa 2011, s. 23 i n.; G. Michałowska, Ochrona praw człowieka w Radzie Europy i w Unii Europejskiej, Warszawa 2007, s. 11 i n.

30 L. Garlicki, Wprowadzenie..., s. 6.

31 Ibidem; podobnie - E. Cała-Wacinkiewicz, Europejska Konwencja o Ochronie Praw Człowieka i Podstawowych Wolności, [w:] Encyklopedia zagadnień międzynarodowych, red. 
Od momentu podpisania Konwencji do dnia oddania niniejszego artykułu do druku zostało przyjętych szesnaście protokołów dodatkowych, uzupełniających lub modyfikujących jej treść, przy czym Protokoły 15 i 16 nie weszły jeszcze w życie ${ }^{32}$.

Protokoły dodatkowe można podzielić na dwie grupy, tj. na protokoły o charakterze ustrojowo-proceduralnym oraz protokoły zawierające postanowienia prawa materialnego. Do pierwszej kategorii należą Protokoły nr 2, $3,5,8,9,10,11,14,15$ i 16. Drugą grupę tworzą natomiast Protokoły nr 1, 4, $6,7,12,13^{33}, 15$ i 16 . Protokoły zawierające postanowienia prawa materialnego, rozszerzające pierwotny katalog wolności i praw ujętych w Konwencji, w przeciwieństwie do protokołów ustrojowo-proceduralnych, wprowadzających dalsze modyfikacje w strasburskim mechanizmie ochrony wolności i praw jednostki, w tym w szczególności w odniesieniu do skargi indywidualnej, nie zostały bezpośrednio wprowadzone do podstawowego tekstu Konwencji, istnieją obok niego ${ }^{34}$. Innymi słowy, pod względem formalnoprawnym pozostają oddzielnymi traktatami (umowami międzynarodowymi) podlegającymi procedurze odrębnej ratyfikacji. Konwencję wyróżnia zatem jej specyficzna konstrukcja prawna, bowiem składa się na nią tekst podstawowy, jak również istniejące obok niego protokoły dodatkowe. Jak wskazano na wstępie, przystąpienie do Konwencji nie przesądza o przystępowaniu do protokołów, lecz nie jest możliwa sytuacja à rebours. W konsekwencji część praw konwencyjnych nie może być dochodzona w niektórych państwach-stronach Konwencji, np. praw przewidzianych w Protokole nr 4 (tj. zakazu pozbawiania wolności za długi, prawa do swobodnego poruszania się wraz ze swobodą wyboru miejsca zamieszkania, zakazu wydalania wła-

E. Cała-Wacinkiewicz, R. Podgórzańska i D. Wacinkiewicz, Warszawa 2011, s. 326.

32 Protokół nr 15 został otwarty do podpisu 24 czerwca 2013 r., zaś Protokół nr 16 2 października 2013 r. Protokół nr 15 wejdzie w życie po podpisaniu i zatwierdzeniu, bądź ratyfikowaniu go przez wszystkie strony Konwencji; natomiast Protokół nr 16 - po ratyfikacji przez dziesięć państw. Tekst Protokołu nr $15 \mathrm{w}$ angielskiej wersji językowej: http:// www.conventions.coe.int/Treaty/Commun/QueVoulezVous.asp?NT=213\&CM=8\&D$\mathrm{F}=08 / 10 / 2014 \& \mathrm{CL}=\mathrm{ENG}(11.08 .2015)$.

Tekst Protokołu nr 16 w angielskiej wersji językowej: http://www.conventions.coe.int/Treaty/ Commun/QueVoulezVous.asp?NT=214\&CM=8\&DF=08/10/2014\&CL=ENG (11.08.2015).

33 I. Malinowska, Ochrona praw i wolności w Polsce, Warszawa 2009, s. 292.

34 L. Garlicki, Wprowadzenie..., s. 6-8. 
snych obywateli, zakazu zbiorowego wydalania cudzoziemców) nie można na tej podstawie dochodzić w Grecji, Szwajcarii, Turcji i Wielkiej Brytanii ${ }^{35}$.

Odnosząc się do przedmiotu regulacji Konwencji, można w jej ramach wyodrębnić trzy zasadnicze grupy postanowień. Pierwszą z nich stanowią postanowienia prawa materialnego, zawierające wyliczenie podstawowych praw i wolności jednostki wraz z określeniem zasad ich stosowania oraz granic ochrony. Uwagę zwraca, że katalog praw i wolności gwarantowanych konwencyjnie nie jest zamknięty. Jest on sukcesywnie uzupełniany w drodze przyjmowania protokołów dodatkowych, odzwierciedlających rozwój doktryny praw człowieka. Można, naszym zdaniem, spodziewać się, że w obliczu nowych problemów, przed którymi staje świat i Europa (np. starzenie się społeczeństw, dostęp do dóbr kultury, ekskluzja społeczna odbywająca się na podstawie różnych kryteriów, choćby ekonomicznego), kolejne protokoły będą zmierzały do objęcia wolności i praw III generacji, tj. ekonomicznych, socjalnych i kulturalnych. Oznaczać to jednocześnie będzie mogło pewne komplikacje związane $\mathrm{z}$ ich ratyfikacją, albowiem - z uwagi na wskazane $\mathrm{w}$ dalszej części artykułu funkcje konstytucyjne Konwencji - kraje tradycyjnie wyłączające wolności i prawa III generacji spośród wolności i praw konstytucyjnych (np. Wielka Brytania) nie będą skore do ich wprowadzenia „tylnymi drzwiami”, przez związanie się nimi w drodze czynności międzynarodowo-prawnej.

Aktualne wyliczenie wolności i praw ujętych w Konwencji daje podstawę do stwierdzenia, że w zasadzie obejmuje ona wyłącznie prawa i wolności osobiste oraz polityczne, co odróżnia ją od przyjętej w ramach Organizacji Narodów Zjednoczonych Powszechnej Deklaracji Praw Człowieka, w której wyróżnia się trzy grupy praw i wolności ${ }^{36}$ (również prawa i wolności ekonomiczne, socjalne i kulturalne). Nadto niektóre z wolności i praw ujętych w Konwencji pokrywają się z wolnościami i prawami gwarantowanymi w Konstytucji Rzeczypospolitej Polskiej z dnia 2 kwietnia 1997 r. ${ }^{37}$ oraz z wolnościami i prawami deklarowanymi w Karcie.

35 http://www.conventions.coe.int/Treaty/Commun/ChercheSig.asp?NT=046\&C$\mathrm{M}=8 \& \mathrm{DF}=10 / 10 / 2014 \& \mathrm{CL}=\mathrm{ENG}(11.08 .2015)$.

36 D. Ostrowska, Z. Hołda, Ochrona praw człowieka w systemie Rady Europy, [w:] Prawa człowieka. Zarys wykładu, red. J. Hołda, Z. Hołda i in., Warszawa 2011, s. 66.

37 Dz.U. Nr 78, poz. 483 ze zm.; B. Szmulik, Skarga konstytucyjna. Polski model na tle porównawczym, Warszawa 2006, s. 294-299. 
Na drugą kategorię postanowień zawartych w Konwencji składają się postanowienia instytucjonalne, ustanawiające szczególny ponadnarodowy organ jurysdykcyjny, dzisiaj-ETPCz, właściwy do rozstrzygania, czy państwa w należyty sposób wypełniają zobowiązania wynikające z Konwencji. Jak zauważa się w piśmiennictwie, ratyfikacja przez państwo EKPCz „owocuje rozciągnięciem płaszcza ochronnego, jaki w aspekcie jurydycznym gwarantuje kognicja ETPCz"38. Tytułem wyjaśnienia wskazać przy tym należy, że pierwotnie - tj. przed reformą wprowadzoną Protokołem nr 11 do EKPCz, który wszedł w życiel listopada 1998 r. - system przestrzegania postanowień Konwencji obejmował dwa organy: Europejską Komisję Praw Człowieka i Europejski Trybunał Praw Człowieka ${ }^{39}$. Oprócz nich, w początkowym okresie funkcjonowania Konwencji istotną rolę odgrywał Komitet Ministrów RE, który nie tylko nadzorował wykonanie orzeczeń Trybunału, ale i sam wydawał orzeczenia w tych sprawach, w których Komisja stwierdziła naruszenie postanowień Konwencji, a nieskierowanych do Trybunału ${ }^{40}$. Przywołany Protokół nr 11 zniósł Europejską Komisję Praw Człowieka oraz Trybunał Praw Człowieka w dotychczasowym kształcie, powołując w ich miejsce nowy, jednolity i stały Europejski Trybunał Praw Człowieka ${ }^{41}$, którego jurysdykcja jest obligatoryjna. Zmiany dokonane tym protokołem okazały się jednak niewystarczające dla rozwiązania problemu ogromnej, wręcz

38 P. Kułak, Konsekwencje objęcia państw Europy Środkoweji Wschodniej kognicja Europejskiego Trybunału Praw Człowieka, [w:] Rada Europy a przemiany demokratyczne w państwach Europy Środkowej i Wschodniej w latach 1989-2009, red. J. Jaskiernia, Toruń 2010, s. 187.

39 S. Jarosz-Żukowska, Europejski system ochrony praw człowieka, [w:] Prawa człowieka i systemy ich ochrony. Zarys wykładu, red. M. Jabłoński i S. Jarosz-Żukowska, Wrocław 2004, s. 243.

40 R. Balicki, Europejski system ochrony praw człowieka, [w:] Prawa człowieka a stosunki międzynarodowe, red. A. Florczak i B. Bolechow, Toruń 2006, s. 74.

${ }_{41}$ A. Bisztyga, Europejski system ochrony praw człowieka, [w:] Prawa $i$ wolności obywatelskie w Konstytucji RP, red. B. Banaszak i A. Preisner, Warszawa 2002, s. 807 i n.; Idem, Reforma Europejskiego Trybunału Praw Człowieka - Protokół Nr 11 do Konwencji Europejskiej, „Humanistyczne Zeszyty Naukowe - Prawa Człowieka” 1996, nr 3, s. 15-26; B. Gronowska, Reforma procedury kontrolnej Europejskiej Konwencji Praw Człowieka z 1950 r. - wybrane zagadnienia, „Przegląd Prawa Europejskiego” 1996, nr 1, s. 91-99; L. Wildhaber, The European Court of Human Rights 1998-2006: History, Achievements, Reform, Strasbourg 2006, s. 37 i n.; N. Rowe, V. Schlette, The Protection of Human Rights in Europe after the Eleventh Protocol to the ECHR, ELR 1998, Supplement, s. 5. 
lawinowej, liczby skarg napływających co roku do Trybunału ${ }^{42}$. Niezbędne stało się w związku z tym powzięcie kolejnych reform w zakresie funkcjonowania Trybunału. Znajdują one odzwierciedlenie w Protokole nr 14, który ostatecznie wszedł w życie zl czerwca $2010 \mathrm{r}^{43}$, oraz dwóch otwartych do podpisu Protokołach nr 15 i nr $16^{44}$.

Trzecią grupę postanowień Konwencji tworzą postanowienia o charakterze proceduralnym, związane z zasadami rozpoznawania spraw i wydawania orzeczeń przez ETPCz, w tym m.in. co do tzw. skarg indywidualnych. Ich uzupełnienie stanowią postanowienia zawarte w Regulaminie Trybuna$\mathrm{fu}^{45}$ oraz liczne instrukcje praktyczne wydawane przez prezesa Trybunału na podstawie art. 32 tegoż Regulaminu ${ }^{46}$.

\section{V.}

Charakteryzując specyfikę EKPCz, zauważyć należy, że w orzecznictwie strasburskim jest określana mianem ,instrumentu konstytucyjnego europejskiego porządku publicznego w dziedzinie praw człowieka (constitutional

42 Por. m.in. statystyki zawierające liczby składanych skarg dostępne pod adresem internetowym http://www.echr.coe.int/Pages/home.aspx?p=reports\&c=\#n13910998878211852726217_ pointer (11.08.2015).

43 Ł. Bojarski, op.cit., s. 18. O istocie zmian przewidzianych w Protokole nr 14 zob. także np.: J. Jaskiernia, Wpływ orzecznictwa Europejskiego Trybunału Praw Człowieka na ustawodawstwo w państwach członkowskich Rady Europy, [w:] Zapewnienie efektywności orzeczeń sadów międzynarodowych w polskim porządku prawnym, red. A. Wróbel, Warszawa 2011, s. 306 i przytoczona tam literatura.

44 Szerzej na ten temat por. Reforma ETPCz - plan działań, http://www.europapraw. org/news/reforma-etpcz-plan-dzialan (18.07.2012); Prace nad Protokołami 15 i 16, http:// www.europapraw.org/news/prace-nad-protokolami-15-i-16-do-ekpc (20.09.2012); Drafting Group B on the Reform of the Court (GT-GDR-B), http://www.coe.int/t/dghl/standardsetting/cddh/GT-GDR-B_e.asp. (11.08.2015).

45 Brak oficjalnego opublikowania w języku polskim. Dostępne jako: Rules of the Court from 1 June 2015 - http://www.echr.coe.int/Documents/Rules_Court_ENG.pdf(11.08.2015).

46 Por. m.in. instrukcję praktyczną dotyczącą wszczęcia postępowania, instrukcję praktyczną dotyczącą pism procesowych czy też instrukcję praktyczną dotyczącą roszczenia o słuszne zadośćuczynienie. Teksty instrukcji praktycznych w angielskiej wersji językowej dostępne są pod adresem internetowym: http://www.echr.coe.int/Pages/home.aspx? p=basictexts/rules\&c= (11.08.2015). 
instrument of European public order in the field of human rights)"47. Co więcej, Konwencja zawiera katalog podstawowych praw i wolności unormowanych na tyle szczegółowo, że nadają się one do bezpośredniego stosowania. Są to normy samowykonalne (self-executing), niepotrzebujące uzupełnień ustawodawczych dla możności ich zastosowania przed sądem państwa-strony danej umowy ${ }^{48}$. W państwach członkowskich RE Konwencja uznawana jest za część krajowego porządku prawnego, dzięki czemu jej postanowienia stały się samodzielną podstawą do dochodzenia roszczeń przed właściwymi organami krajowymi i konwencyjnymi. W Polsce Konwencja również stanowi część krajowego porządku prawnego i jest bezpośrednio stosowana, przy czym jako umowa międzynarodowa ratyfikowana za uprzednią zgodą wyrażoną w ustawie ma pierwszeństwo przed ustawą, jeżeli ustawy nie da się pogodzić z jej treścią ${ }^{49}$. Wskutek przyjęcia takiego rozwiązania nie jest ona wyłącznie szczytną deklaracją wzniosłych intencji (aktem o charakterze ideowo-programowym), lecz skutecznym środkiem dochodzenia określonych wolności i praw ${ }^{50}$. Jak dobitnie stwierdziła Ewa Łętowska, Konwencja w Polsce zapoczątkowała „nowe myślenie o prawie” ${ }^{51}$.

Doniosłość i innowacyjność EKPCz wyraża się także w ukonstytuowaniu przez nią europejskiego mechanizmu jurysdykcyjnej ochrony wskazanych

47 Zob. m.in. \$ 155-156 wyroku ETPCz z dnia 30 czerwca 2005 r. w sprawie Bosphorus Hava Yollari Turizmve Ticaret Anonim Sirketi przeciwko Irlandii, skarga nr 45036/98, LexPolonica nr 392381; \$ 80 decyzji ETPCz z dnia 12 grudnia 2001 r. w sprawie Bankoviè i inni przeciwko Belgii i innym, skarga nr 52207/99 [za:] http://hudoc.echr.coe.int/sites/eng/Pages/search.aspx\#\{„appno”:[„52207/99”],”itemid”:[„001-22099”]\} (11.08.2015); \$ 145 decyzji ETPCz z dnia 31 maja 2007 r. w sprawie Agim Behrami i Bekir Behrami przeciwko Francji (skarga nr 71412/01) oraz RuzhdiSaramati przeciwko Francji, Niemcom i Norwegii (skarga nr 78166/01), [za:] http://hudoc.echr.coe.int/sites/eng/Pages/search.aspx\#\{fulltext”:[Ruzhdi Saramati”],”itemid”:[„001-80830”]\} (11.08.2015).

48 R. Kwiecień, Miejsce umów międzynarodowych w porzadku prawnym państwa polskiego, Warszawa 2000, s. 137-138; C.M. Vázquez, The Four Doctrins of Self-executing Treaties, „Georgetown Public Law and Legal Theory Research Paper”, nr 12-01, Georgetown 1995, s. $695-696$.

49 Por. art. 91 ust. 1 i 2 Konstytucji Rzeczypospolitej Polskiej.

50 W. Lis, Z. Husak, Powszechny charakter orzecznictwa Europejskiego Trybunatu Praw Człowieka, „Jurysta” 2009, nr 1, s. 6.

51 Por. E. Eętowska, Konwencja Europejska w Polsce i nowe myślenie o prawie, „Kwartalnik Prawa Prywatnego” 1992, nr 1-5, s. 147-160. 
powyżej wolności i praw w aspekcie instytucjonalnym, poprzez powołanie ponadnarodowego organu sądowego - aktualnie: ETPCz. Trybunał poprzez swoje orzecznictwo wytycza ramy wolności i praw zawartych w Konwencji oraz wypełnia je treścią, nierzadko za pomocą twórczej „ekstensywnej” wykładni jej postanowień. To dzięki jego aktywności Konwencja traktowana jest jako „żywy instrument”, interpretowany z uwzględnieniem ciągle zmieniającej się rzeczywistości ${ }^{52}$. Interpretacja taka możliwa jest $\mathrm{z}$ uwagi na zachowanie maksymalnej ogólności postanowień Konwencji, uelastyczniających ją w kontekście coraz to szybszych zmian rzeczywistości, w jakiej znajduje zastosowanie. Konwencja została bowiem z założenia skonstruowana pro aeternitas. W pełni uzasadnione staje się w związku z tym twierdzenie, że de facto nie jest możliwe zrozumienie w pełni postanowień Konwencji bez odwołania się do treści orzeczeń wydanych przez powołane na jej podstawie organy (Komisję, ETPCz). Orzecznictwo strasburskie, konkretyzujące normy konwencyjne, określa bowiem uniwersalne standardy w zakresie ochrony wolności i praw człowieka ${ }^{53}$ uznawane za wspólne dla państw europejskich. Autonomicznym pojęciom konwencyjnym Trybunał nadaje jak najszersze znaczenie, postępując niejako jak sąd konstytucyjny uzupełniający w swym orzecznictwie treść ustawy zasadniczej ${ }^{54}$.

Szczególnie istotna jest przy tym okoliczność, że system ochrony zagwarantowany w Konwencji zakłada możliwość składania nie tylko skarg międzypaństwowych, ale także (i przede wszystkim) skarg indywidualnych. W tym aspekcie Konwencja nie ma w systemie ochrony praw człowieka charakteru „szablonowego" traktatu międzynarodowego. Stanowi bowiem wyłom w klasycznym prawie międzynarodowym, tradycyjnie wykluczającym prawnomiędzynarodową podmiotowość jednostki ${ }^{55}$, będąc pierwszą umową przyznającą jednostce prawo do zaskarżania działań (prawnych, jak i faktycznych) oraz zaniechań państwa na forum międzynarodowym, a tym

52 Por. wyrok ETPCz z dnia 25 kwietnia 1978 r. w sprawie Tyrer przeciwko Zjednoczonemu Królestwu, nr skargi 5856/72, Lex Polonica, nr 402824.

53 Zob.np. S. Greer, The European Convention on Human Rights: Achievements, Problems and Prospects, Cambridge 2006, s. 46.

54 O takiej funkcji sądów konstytucyjnych por. P. Holländer, Uzupetnianie Konstytucji orzecznictwem Sądu Konstytucyjnego, „Przegląd Sejmowy” 2004, nr 6, s. 9-26.

55 L. Antonowicz, Podręcznik prawa międzynarodowego, Warszawa 2011, s. 22-24. 
samym czyniącą ją podmiotem (a nie przedmiotem) prawa międzynarodowego. Inaczej niż inne traktaty międzynarodowe, Konwencja nie reguluje stosunków między państwami, lecz ustala standardy ich zachowań wobec jednostek podległych ich jurysdykcji. W orzecznictwie samego Trybunału wskazuje się, że Konwencja zawiera więcej niż tylko dwustronne zobowiązania państw, a jest traktatem mającym na celu zbiorowe zagwarantowanie podstawowych wolności i praw człowieka ${ }^{56}$.

O doniosłości EKPCz świadczy wreszcie fakt, że stała się ona źródłem inspiracji dla innych regionalnych systemów ochrony praw człowieka, np. dla amerykańskiego czy dla afrykańskiego ${ }^{57}$.

VI.

Jak zauważa Robert Uerpmann, EKPCz w krajowych porządkach prawnych przypadają także pewne funkcje konstytucyjne. Zagadnienie to różnie kształtuje się w poszczególnych państwach, niemniej jednak można dojść do indukcyjnego wniosku, że rola Konwencji w krajowym porządku prawnym determinowana jest dwoma następującymi czynnikami. Primo, jakością (standardem) krajowej ochrony praw człowieka. Secundo, sposobem, w jaki Konwencja została inkorporowana do prawa krajowego. Jeżeli krajowy katalog praw człowieka nie jest zupełny, Konwencja spełnia funkcję wypełniania tychże luk. Gdy zaś Konwencja zajmuje wysoką rangę w krajowym porządku prawnym, szczególna doniosłość przypada funkcji wzorca dla decyzji podejmowanych przez organy stosujące prawo. Jeżeli natomiast krajo-

56 M. Matyasik, Polska w systemie ochrony praw człowieka Rady Europy, [w:] Prawa człowieka. Wybrane zagadnienia i problemy, red. L. Koba, W. Wacławczyk, Warszawa 2009, s. 95; K. Machowicz, Ochrona praw człowieka w Rzeczypospolitej Polskiej na tle standardów europejskich, Lublin 2009, s. 18-19; A. Redelbach, Strasbourg bliżej. Skargi indywidualne do Europejskiej Komisji Praw Człowieka, Poznań 1966, s. 12. Wyrok ETPCz z dnia 18 stycznia 1978 r. w sprawie Irlandia przeciwko Zjednoczonemu Królestwu, nr skargi 5310/71, Lex Polonica, nr 402821.

57 P. Walczak, Warunki dopuszczalności skargi indywidualnej na podstawie Europejskiej Konwencji Praw Człowieka, „Państwo i Prawo” 1993, z. 8, s. 48; M. Gołaś-Podolec, Porównanie europejskiego i interamerykańskiego systemu ochrony praw człowieka, „Krakowskie Studia Międzynarodowe” 2008, nr 2, s. 155-182. 
wy porządek prawny jest wystarczająco pełny (co do zasady postanowienia konwencyjne odnajdują odzwierciedlenie w postanowieniach prawa krajowego) i elastyczny, aby w każdym momencie umożliwić przychylną Konwencji interpretację, funkcja Konwencji sprowadza się jedynie dodawania impulsu dla rozwoju prawa konstytucyjnego, a także wpływania na „prokonwencyjną" wykładnię ustawodawstwa zwykłego ${ }^{58}$.

W kontekście poczynionych rozważań, nie można jednak abstrahować od tego, że dla określenia skuteczności i znaczenia Konwencji w danym państwie istotną rolę odgrywają dwa sprzężone ze sobą czynniki: 1) liczba skarg wpływających do ETPCz oraz 2) poziom wykonalności (egzekwowalności) jego orzeczeń. Wśród pięciu państw, przeciwko którym zawisło najwięcej spraw, a zatem w których poziom ochrony praw człowieka najwyraźniej nie odpowiada minimalnym standardom konwencyjnym, zgodnie ze statystykami opublikowanymi przez Trybunał ${ }^{59}$, znajdują się Ukraina (19,5\%), Włochy $(14,4 \%)$, Rosja (14,3\%), Turcja (13,6\%) oraz Rumunia (4,9\%). Dodatkowo warto nadmienić, że w dniu 1 lipca 2015 r. Sąd Konstytucyjny Federacji Rosyjskiej stwierdził, że wyroki ETPCz mogą być wykonane tylko wtedy, jeżeli będzie to wynikało „Z nadrzędności konstytucji Federacji Rosyjskiej”"60. Otwiera to możliwość dowolnego ingerowania w rzeczywistą skuteczność tych orzeczeń przez władze państwowe, a zatem wyłącza w całości zasadę subsydiarnej ochrony, stanowiącą podwaliny europejskiego systemu ochrony jednostki.

\section{VII.}

EKPCz od ponad sześćdziesięciu lat wyznacza materialny standard ochrony praw człowieka w Europie. Podsumowując poczynione rozważania i rekapitulując argumenty za uznaniem tezy o fundamentalnej prawno-politycznej doniosłości EKPCz, wskazać należy na kilka okoliczności.

58 R. Uerpmann, Konstytucyjne funkcje Europejskiej Konwencji Praw Człowieka, http:// epub.uni-regensburg.de/22429/1/Uerpmann_ECHR_Wroclaw.pdf (11.08.2015).

59 http://www.echr.coe.int/Pages/home.aspx?p=reports\&c= (11.08.2015).

60 http://www.obserwatorkonstytucyjny.pl/swiat/rosja-sad-konstytucyjny-bedziebadal-wyroki-etpc-i-innych-sadow-miedzynarodowych (11.08.2015). 
Po pierwsze, EKPCz ustanawia europejską gwarancję podstawowych wolności i praw człowieka w aspekcie materialnoprawnym. Stanowi bowiem prawnomiędzynarodową kodyfikację osobistych i politycznych wolności i praw o podstawowym charakterze (tzw. praw pierwszej i drugiej generacji).

Po drugie, w odróżnieniu od "klasycznych” umów międzynarodowych, pozostawiających wykonywanie swych postanowień w sferze ogólnej odpowiedzialności państw - sygnatariuszy, EKPCz wprowadziła własny mechanizm implementacyjny, polegający na ukonstytuowaniu europejskiego mechanizmu jurysdykcyjnej ochrony wolności i praw w aspekcie instytucjonalnym, tj. powołaniu ponadnarodowego organu sądowego - ETPCz (właściwego do rozstrzygania, czy państwa-strony respektują postanowienia Konwencji i jej protokołów). Naszym zdaniem, o sukcesie działań ETPCz (a tym samym praktycznym znaczeniu Konwencji) można mówić wtedy, kiedy nie tylko jednostka czy inny podmiot prawa uzyskała jakąś formę rekompensaty za naruszenie jej wolności lub praw, ale także gdy orzeczenie wywarło skutki prawne w sferze prewencyjnej oraz w sferze umocnienia krajowego systemu ochrony, tj. gdy zostało uwzględnione w prawie i praktyce krajowej organów stosujących prawo.

Po trzecie, Konwencja zapewniła bezpośredni dostęp jednostki do ETPCz $\mathrm{W}$ aspekcie proceduralnym poprzez instytucję skargi indywidualnej, $\mathrm{z}$ jaką w świetle art. $34 \mathrm{EKPCz}$ - wystąpić może każda osoba (zarówno fizyczna, jak i prawna), organizacja pozarządowa lub grupa jednostek, uważająca się za ofiarę naruszenia przez państwo wolności lub praw konwencyjnych. Wprowadzenie takiej możliwości stanowiło wyłom w tradycyjnym postrzeganiu stosunków prawnomiędzynarodowych, których podmiotami były dotąd wyłącznie państwa i tzw. szczególne podmioty prawa międzynarodowego ${ }^{61}$.

Po czwarte, w państwach-stronach Konwencja została, choć pod różną postacią, inkorporowana do systemu prawa wewnętrznego i jest bezpośrednio stosowana przez krajowe władze publiczne, w tym zwłaszcza sądy. Nie jest zatem aktem jedynie o charakterze ideowo-programowym,

${ }^{61}$ Przez szczególne podmioty prawa międzynarodowego należy rozumieć m.in. Suwerenny Zakon Kawalerów Maltańskich, Stolicę Apostolską, terytoria autonomiczne, wspólnoty powstańcze, organizacje międzynarodowe -L. Antonowicz, Podręcznik..., s. 23; M.N. Shaw, Prawo międzynarodowe, Warszawa 2006, s. 134-173; L. Ehrlich, Prawo międzynarodowe, Warszawa 1958, s. 107-161. 
lecz może stanowić skuteczny środek dochodzenia roszczeń związanych $\mathrm{z}$ naruszeniem wolności lub praw jednostki przed organami stosującymi prawo ${ }^{62}$.

Po piąte, Konwencja wypełnia także funkcje konstytucyjne (tj. funkcję uzupełniania luk, funkcję wzorca oraz funkcję impulsu), przy czym stopień natężenia ich realizacji kształtuje się odmiennie w poszczególnych państwach - stronach.

\section{VIII.}

W naszej ocenie, żaden inny akt prawa międzynarodowego nie może być, ani $\mathrm{w}$ aspekcie prawno-politycznym, ani dostępności dla jednostek, porównywany z Konwencją. Biorąc pod uwagę okoliczności jej powstania, normatywną treść oraz mechanizm implementacyjny, nie może budzić wątpliwości, dlaczego Konwencję uznaje się za „perłę (klejnot) w koronie” Rady Europy ${ }^{63}$, przesądzający o percepcji tej organizacji jako całości ${ }^{64}$. Jak zauważa Jerzy Jaskiernia, system konwencyjny Rady Europy, składający się w szczególności z EKPCz, „tworzy dzisiaj zasadniczy zręb europejskiej przestrzeni prawnej i ma istotne znaczenie w procesie unifikacji i zbliżania prawa europejskiego pojmowanego sensu largo"65. Naszym zdaniem, nie można jednak zapominać, że aktualnie obecność w europejskiej przestrzeni prawnej Karty Praw Podstawowych Unii Europejskiej oraz słabość Rady Europy, pod której auspicjami przyjęto przecież EKPCz, znajdująca wyraz w tym, że zrzesza ona dużą liczbę państw o zróżnicowanej kulturze prawnopolitycznej oraz zróżnicowanych standardach demokracji, sprawiają, że praktyczna doniosłość Konwencji ulega i - jak należy się spodziewać będzie ulegać ciągłej weryfikacji.

62 Dostęp obywateli do europejskiego wymiaru sprawiedliwości, red. H. Izdebski, H. Machińska, Warszawa 2005.

63 J. Jaskiernia, Wptyw..., s. 292.

64 M.B. Demobnour, Who Believes in Human Rights: Achievements, Problems and Prospects, Cambridge 2006, s. 45.

65 J. Jaskiernia, Rada Europy jako organizacja międzynarodowa kreujacca i oddziałujaca na implementację standardów demokratycznych, [w:] Rada Europy a przemiany..., s. 34. 


\section{Literatura}

Antonowicz L., Podręcznik prawa międzynarodowego, Warszawa 2011.

Bisztyga A., Geneza Europejskiej Konwencji o Ochronie Praw Człowieka i Podstawowych Wolności oraz Europejskiego Trybunału Praw Człowieka, „Humanistyczne Zeszyty Naukowe - Prawa Człowieka" 1994, nr 1.

Bisztyga A., Reforma Europejskiego Trybunału Praw Człowieka - Protokół Nr 11 do Konwencji Europejskiej, „Humanistyczne Zeszyty Naukowe - Prawa Człowieka” 1996, nr 3.

Bisztyga A., Europejski system ochrony praw człowieka, [w:] Prawa i wolności obywatelskie w Konstytucji RP, red. B. Banaszak, A. Preisner, Warszawa 2002.

Bisztyga A., Europejski Trybunat Praw Człowieka, Katowice 1997.

Bisztyga A., Ochrona praw człowieka w Radzie Europy, [w:] B. Banaszak, A. Bisztyga, K. Complak, M. Jabłoński, R. Wieruszewski, K. Wójtowicz, System ochrony praw człowieka, Kraków 2003.

Balicki R., Europejski system ochrony praw człowieka, [w:] Prawa człowieka a stosunki międzynarodowe, red. A. Florczak i B. Bolechow, Torun 2006.

Bojarski Ł., Rada Europy i Europejski Trybunał Praw Człowieka - podstawowe informacje, [w:] Europejska Konwencja Praw Człowieka - Poradnik Praktyczny, red. Ł. Bojarski, M. Krzyżanowska-Mierzewska, Warszawa 2011.

Cała-Wacinkiewicz E., Europejska Konwencja o Ochronie Praw Człowieka i Podstawowych Wolności, [w:] Encyklopedia zagadnień międzynarodowych, red. E. CałaWacinkiewicz, R. Podgórzańska, D. Wacinkiewicz, Warszawa 2011.

Demobnour M.B., Who Believes in Human Rights: Achievements, Problems and Prospects, Cambridge 2006.

Dostęp obywateli do europejskiego wymiaru sprawiedliwości, red. H. Izdebski, H. Machińska, Warszawa 2005.

Ehrlich L., Prawo międzynarodowe, Warszawa 1958.

Garlicki L., Wprowadzenie, [w:] Konwencja o Ochronie Praw Człowieka i Podstawowych Wolności. Tom I. Komentarz do artykutów 1-18, red. L. Garlicki, Warszawa 2010.

Garlicki L., Przystapienie UE do Europejskiej Konwencji Praw Człowieka - przygotowania i problemy, „Europejski Przegląd Sądowy” 2011, nr 1.

Gołaś-Podolec M., Porównanie europejskiego i interamerykańskiego systemu ochrony praw człowieka, „Krakowskie Studia Międzynarodowe” 2008, nr 2.

Greer S., The European Convention on Human Rights: Achievements, Problems and Prospects, Cambridge 2006.

Gronowska B., Reforma procedury kontrolnej Europejskiej Konwencji Praw Człowieka z 1950 r. - wybrane zagadnienia, „Przegląd Prawa Europejskiego” 1996, nr 1. 
Harris J., O’Boyle M., Bates E.P., Buckley C.M., Law of the European Convention on Human Rights, Oxford 2009.

Holländer P., Uzupetnianie Konstytucji orzecznictwem Sądu Konstytucyjnego, „Przegląd Sejmowy" 2004, nr 6.

Janis M.W., Kay R.S., Bradley A.W., European Human Rights Law. Text and Materials, Oxford 2007.

Jarosz-Żukowska S., Europejski system ochrony praw człowieka, [w:] Prawa człowieka i systemy ich ochrony. Zarys wykładu, red. M. Jabłoński, S. Jarosz-Żukowska, Wrocław 2004.

Jaskiernia J., Rada Europy jako organizacja międzynarodowa kreująca i oddziałująca na implementacje standardów demokratycznych, [w:] Rada Europy a przemiany demokratyczne w państwach Europy Środkowej i Wschodniej w latach 1989-2009, red. J. Jaskiernia, Toruń 2010.

Jaskiernia J., Rada Europy jako „organizacja wartości”, [w:] Wyjaśnianie polityki, red. J. Błuszkowski, J. Zaleśny, Warszawa 2010, nr 17.

Jaskiernia J., Wpływ orzecznictwa Europejskiego Trybunału Praw Człowieka na ustawodawstwo w państwach członkowskich Rady Europy, [w:] Zapewnienie efektywności orzeczeń sądów międzynarodowych w polskim porządku prawnym, red. A. Wróbel, Warszawa 2011.

Kastory A., Winston Churchill, Wrocław 2004.

Król M., Wielcy władcy. Richelieu, Bismarck, de Gaulle, Churchill, Warszawa 2014.

Kułak P., Konsekwencje objęcia państw Europy Środkowej i Wschodniej kognicja Europejskiego Trybunału Praw Człowieka, [w:] Rada Europy a przemiany demokratyczne w państwach Europy Środkowej i Wschodniej w latach 1989-2009, red. J. Jaskiernia, Toruń 2010.

Kuźniar R., Prawa człowieka. Prawo, instytucje, stosunki międzynarodowe, Warszawa 2002.

Kwiecień R., Miejsce umów międzynarodowych w porządku prawnym państwa polskiego, Warszawa 2000.

Lis W., Husak Z., Powszechny charakter orzecznictwa Europejskiego Trybunatu Praw Człowieka, „Jurysta” 2009, nr 1.

Łętowska E., Konwencja Europejska w Polsce i nowe myślenie o prawie, „Kwartalnik Prawa Prywatnego" 1992, nr 1-5.

Machowicz K., Ochrona praw człowieka w Rzeczypospolitej Polskiej na tle standardów europejskich, Lublin 2009.

Malinowska I., Ochrona praw i wolności w Polsce, Warszawa 2009.

Matyasik M., Polska w systemie ochrony praw człowieka Rady Europy, [w:] Prawa człowieka. Wybrane zagadnienia i problemy, red. L. Koba, W. Wacławczyk, Warszawa 2009. 
Michałowska G., Ochrona praw człowieka w Radzie Europy i w Unii Europejskiej, Warszawa 2007.

Mik C., Przystapienie Unii Europejskiej do Europejskiej Konwencji o Ochronie Praw Człowieka i Podstawowych Wolności, [w:] Europejska Konwencja Praw Człowieka i jej system kontrolny - perspektywa systemowa i orzecznicza, red. M. Balcerzak, T. Jasudowicz, J. Kapelańska-Pręgowska, Toruń 2011.

Morawska H., Gałka K., Standardy ochrony praw człowieka w prawie Europejskiej Konwencji Praw Człowieka. Analiza wiodacych spraw polskich, Warszawa 2011.

Mowbray A., Cases and Materials on the European Convention on Human Rights, Oxford 2006.

Osiatyński W., Prawa człowieka i ich granice, Warszawa 2011.

Ostrowska D., Hołda Z., Ochrona praw człowieka w systemie Rady Europy, [w:] Prawa człowieka. Zarys wykładu, red. J. Hołda, Z. Hołda, D. Ostrowska, J.A. Rybczyńska, Warszawa 2011.

Płachta A., Prawo WE i UE a Konwencja o ochronie praw człowieka i podstawowych wolności, [w:] Stosowanie prawa Unii Europejskiej przez sady, red. A. Wróbel, Warszawa 2010.

Podgórski B., Józef Retinger - prywatny polityk, Kraków 2013.

Półtorak N., Przystąpienie Unii Europejskiej do Konwencji o Ochronie Praw Człowiekaprojekt umowy akcesyjnej a prawo UE, „Europejski Przegląd Sądowy” 2012, nr 9.

Redelbach A., Strasbourg bliżej. Skargi indywidualne do Europejskiej Komisji Praw Człowieka, Poznań 1966.

Rowe N., Schlette V., The Protection of Human Rights in Europe after the Eleventh Protocol to the ECHR, ELR 1998, Supplement.

Shaw M.N., Prawo międzynarodowe, Warszawa 2006.

Szmulik B., Skarga konstytucyjna. Polski model na tle porównawczym, Warszawa 2006.

Terlecki O., Barwne życie szarej eminencji, Kraków 1981.

Terlecki O., Kuzynek diabła, Kraków 1988.

Uerpmann R., Konstytucyjne funkcje Europejskiej Konwencji Praw Człowieka, http:// epub.uni-regensburg.de/22429/1/Uerpmann_ECHR_Wroclaw.pdf (11.08.2015).

Vázquez M., The Four Doctrines of Self-executing Treaties, „Georgetown Public Law and Legal Theory Research Paper”, nr 12-101, Georgetown 1995.

Walczak P., Warunki dopuszczalności skargi indywidualnej na podstawie Europejskiej Konwencji Praw Człowieka, „Państwo i Prawo” 1993, z. 8.

Wildhaber L., The European Court of Human Rights 1998-2006: History, Achievements, Reform, Strasbourg 2006.

Wróbel A., Wprowadzenie. Uwagi ogólne, [w:] Karta Praw Podstawowych Unii Europejskiej. Komentarz, red. A. Wróbel, Warszawa 2012. 